\title{
Emakume bertsolariak ezagutzen
}

\author{
Gema Lasarte Leonet, Anabel Ugalde Gorostiza, Amaia Alvarez-Uria \\ eta Judit Martinez Abajo \\ GIC 18/58. IKHEZI ikerketa-taldea, EHU/UPV
}

\begin{abstract}
Emakume bertsolarien historia ahalduntze-paradigma baten historia bilakatu da (autorea et al., 2016). Ahalduntze-paradigma horrek hainbat ezaugarri ditu. Lehena, bertsolari emakumeen ukazioa edo ahanztura da; ikertzaile gutxi dira emakume bertsolariak aipatzen dituztenak. Bigarren ezaugarria, emakume bertsolariak bi bider isilduak izan dira hastapenetan: emakumeak izateagatik eta pobreen kulturaz kanturako baliatzeagatik (Ugalde, 2018). Hirugarrenik, Carmen Larrañagak (1995, 2000) kritikatu izan du orain arte bertsolaritza inprobisazioarekin, plazarekin eta gizonekin lotu izan dela, gauzak asko sinplifikatuz aniztasunaren kaltean. Emakume bertsolarien historia irakurtzeko, bestalde, ahalduntze-prozesua (Malhotra, 2002) paradigmatzat hartu dugu. Oinarritze teoriko horietatik abiatuta, marko enpirikoan, egungo 200 emakume bertsolari itaundu ditugu euren profila ezagutze aldera. Horrez gain, 25 bertsolari eta bertsoetan adituak direnekin emakume bertsolarien historiaz aritu gara eztabaida-taldeen eta errelatoen bidez. Ondorio nagusi bezala aurrera dezakegu antzinako emakume bertsolariek kantatu zutelako existitzen direla gaur egungo emakume bertsolariak. Eta ordutik honantz nahiz eta bertso-eskolen sorrerak emakume bertsolarien historia ikusgarri bihurtu, emakume bertsolariek botere-gatazkan erresistitzen eta negoziatzen jardun dutela gaur arte eta dihardutela gaur egun. Horren ondorioz, barne- eta talde-boterea landu dute, barne-kontzientzia urteen joanean garatuz eta azken hamarkadetan kontzientzia kolektiboa sortuz.
\end{abstract} Historia.

GAKO-HITZAK: Emakume bertsolariak · Ahalduntzea · Agentzia · Boterea ·

\section{Getting to know the women bertsolaris}

The history of bertsolaris is a paradigm of empowerment. The negation or oblivion of the bertsolaris, in the first place. The double marginalization of improvisers in their beginnings: for being women and for singing in a popular culture, in second place. And finally, the direct relationship that has been established systematically between the improvisation and men has characterized the history of Bertsolaris women. This study in order to propose the reading of the history of bertsolaris as a process of empowerment (Malhotra, 2015), surveyed 200 bertsolaris and conducted five focus group with 20 bertsolaris. In this way, it concludes that the current improvisers sing because previously others sang. And from their beginning, the improvisers have fought, resisted and negotiated the power, developing internal and group consciousness, which derives in a process of empowerment from the last two decades.

KEY WORDS: Women bertsolaris · Empowerment - Agency · Power · Oral literature. 


\section{Sarrera ${ }^{1}$}

Emakume bertsolarien historia ahalduntze-paradigma baten historia bilakatu da (autora et al., 2016). Ahalduntze-paradigma horrek hainbat ezaugarri ditu. Lehena, bertsolari emakumeen ukazioa edo ahanztura da; ikertzaile gutxi dira emakume bertsolariak aipatzen dituztenak. Horrela, esan daiteke XVIII. menderako bertsolaritza erabat sustraitua zegoela Euskal Herri guztian Ipar nahiz Hego aldean, bai forma aldetik bai gizartean errotua, bertsotan gizonek nahiz emakumeek egiten zutela (Ugalde, 2018). Hori horrela izanik ere, bertsolaritza, oro har, ez da hagitz azaltzen dokumentazio-iturrietan. Izan ere, ia gaur arte bertsogileak arlote, mozkor, ezjakintzat hartu izan dira (Barandiaran, 2013) eta paper kultuetan ez dute lekurik merezi izan. Agintariek, elizakoek herriaren artea kontsideratzen zuten bertsolaritza. Beraz, bigarren ezaugarri modura esan genezake emakume bertsolariak bi bider isilduak izan direla beren hastapenetan: emakumeak izateagatik eta pobreen kultura kanturako baliatzeagatik (Ugalde, 2018). Hirugarrenik, Carmen Larrañagak (1995, 2000) kritikatu izan du orain arte bertsolaritza inprobisazioarekin, plazarekin eta gizonekin lotu izan dela, gauzak asko sinplifikatuz aniztasunaren kaltean. Guk ere bat egiten dugu ikerketa honetan Larrañagarekin, gizonak ez ezik emakumeak ere egon direlako eta, bat-batekotik haraindi, bertsoak beste bideak ere egin dituelako bere ibilbidean.

Dena den, hasierak bertsolaritzarentzat zailak izan ziren. Bazterreko guneetan topatu zuen lekua: sukalde, taberna eta sagardotegietan. Eta horietan, lehengoan izan ezik, emakumeek ez zuten sarbiderik izan, bertako langileak ez baziren bederen (Ugalde, 2018). Gizonezkoen bertsolaritzaren historia egitea zaila izan bada esandako arrazoiengatik, emakumeena egitea nekezagoa izan da. Horrela, Esteban de Garibayk (1854) aipatzen ditu estreinakoz XV. mendeko hiletetan kantuan azaltzen ziren eresiak. Emakume haiek hildakoei kantatzen zieten. Artelanetan ere izan zuten isla emakume horiek, betiere heriotzaren inguruko errepresentazioetan. Horren lekuko dugu Errioxako Cañasko Erdi Aroko Monastegian, Urraca Díaz de Haro abadesaren hilobia (XIII. mendearen amaiera). Hilkutxaren eskuma aldean, gainean eta alboan azaltzen dira eresiak (Ugalde, 2018).

Negarti edota erostari haiek, bestalde, unibertsalak ziren eta oso errotuta zeuden. Emakume erostariek samina azaltzen zuten hildakoen bizitza gogoratuz erromantze gisako kantuen bidez. Caro Barojaren esanetan (1972), XVI. mendean desagertu ziren gurean, baina egile berak geroago (2000) adierazi zuen bazirela Bizkaian herriak, XIX. mendearen erdialdean oraindik, negartiak zituztenak. Batzuek negar eta zalaparta baino ez zuten egiten, eta beste batzuek «hiletak» kantatzen zituzten (Ugalde, 2018). Munduan zehar barreiatuta egon dira, lehen esan dugun bezala, heriotzari kantatzen zioten emakumeak. Oraindik orain emakume ahundariek badiraute, adibidez, Finlandia aldeko Karelian. Elizabeth Tolbert (1990) ikertzaile feministak Finlandia aldeko Kareliako itkusivirsi-a ikertu du. Ikertzaile horrek aipatzen du emakumeak jaiotzaren eta heriotzaren erritualarekin lotzen direla, amak direlako mundura bizitza ekartzen dutenak eta eurak direlako adio esateko ahalmena dutenak (Tolbert, 2016). Erritual horren bidez, kantuaren eta musikaren

1. Ikerketa honek Emakunde eta EHUren dirulaguntza jaso du 2015-2017 bitartean.

UZTARO 110, 39-60

Bilbo, 2019ko uztaila-iraila 
bidez, hildakoaren arimari laguntzen zaio egin beharreko bidaian. Erdi Aroan ez ezik aurrerago ere euskal kulturan amak heriotzaren erritualarekin lotuak antzeman dira (Aretxaga, 1988; Del Valle, 1985).

Erdi Aroko, Aro Modernoko nahiz Aro Garaikideko andre bertsolariek badute ezaugarri pareko bat: isilduak izana; bertsolaritza ezagutzen denetik bertsotan aritu badira ere (Hernández, 2014). Emakume bertsolarien historiarekin jarraituz, eta historia garaikidera etorriz, gizonezkoena zen espaziotik edota literaturatik, isiltasunetik emakume bakan batzuk ondorengo mendeetan ezagutzen hasiko dira: Plazida Otaño (1867), Joxepa Antoni Aranberri (1865) edota Joxepa Matea Zubeldia (1867) besteak beste (ikus 1. taula). 80-90eko hamarkadetan, ordea, gora egingo du emakume bertsolarien ikusgarritasunak, 1985ean lehen aldiz txapelketa batean emakume bat ikusi zen: Kristina Mardaras. Bertso-eskoletan ere lehen emakume bertsolaria agertu zen: Arantzazu Loidi eta orduz geroztikakoak ditugu gai honen inguruko ikerketak. 1988an Arantzazu Loidiri galdera hau jarri zioten gaitzat: Zer sentitzen duzu emakume izanez bertsolari izatean? Hona erantzuna (Izagirre, 2014).

Pixka pixka bat kostatu zait esaldi hau ahaztea / bertsolaria emakumea / eta gainera gaztea, / nik nahiago dut kontu horiek/ alde batera uztea / problema ez da sexu kontua, / baizik ona izatea.

Gauzak horrela, artikulu honetan emakume bertsolariak bisibilizatzen edota emakume bertsolarien historiara hurbiltzen ahaleginduko gara. Horretarako marko teorikoan lehenik, Joxerra Gartziak (2012) egindako bertsolaritzaren historia laburtuari hainbat ekarpen egingo dizkiogu, emakume batzuk izendatuz, eta, ondoren, kulturaanalisietan, marko teorikoarekin jarraiki, emakumeak objektu izatetik subjektu ahaldundua izateko bidean teoria feministatik emandako argibideetan hartuko dugu oin. Oinarritze teoriko horietatik abiatuta, marko enpirikoan emakume bertsolarien historia ezagutzen ahaleginduko gara. Hartara, egungo emakume bertsolarien profilaren zertzelada batzuk emango ditugu, eta jarraian, eurek emakume bertsolarien inguruan duten ezagutza dela medio, emakume bertsolarien historia irakurtzeko proposamena luzatuko dugu.

\section{Bertsolaritzaren historian emakume bertsolarien ahalduntzea}

Gure irakurketa-proposamena boterearen eta ikusgarritasunaren gainean eraikia dago. Horrela, emakume bertsolarien historian hiru aldi ikusi ditugu. Lehena, hasieratik bertso-eskolen eskutik emakumeak ikusten hasi artekoa. Bigarren eta hirugarren aldiak emakumea ikusten, erresistitzen eta ahalduntzen hasten direnak lirateke, hau da, 1980 tik eta 2000 urtetik gaurdaino.

Ahalduntzeaz hitz egiten denean, botere-harremanen inguruan hitz egiten da (Foucault, 1972; Gramsci, 1971; Freire, 1986) eta botere-iturrietatik kontrol handiagoa lortze aldera, existitzen diren botere-harremanak kolokan jartzearen premiaz (Murguialday, 2013). Beste modu batean esanda, emakumeen mendeko egoera genero-perspektibatik eraikitzen duten egitura eta prozesuen aldaketa erradikalaren beharraz dihardugu (Oakley, 2001). 


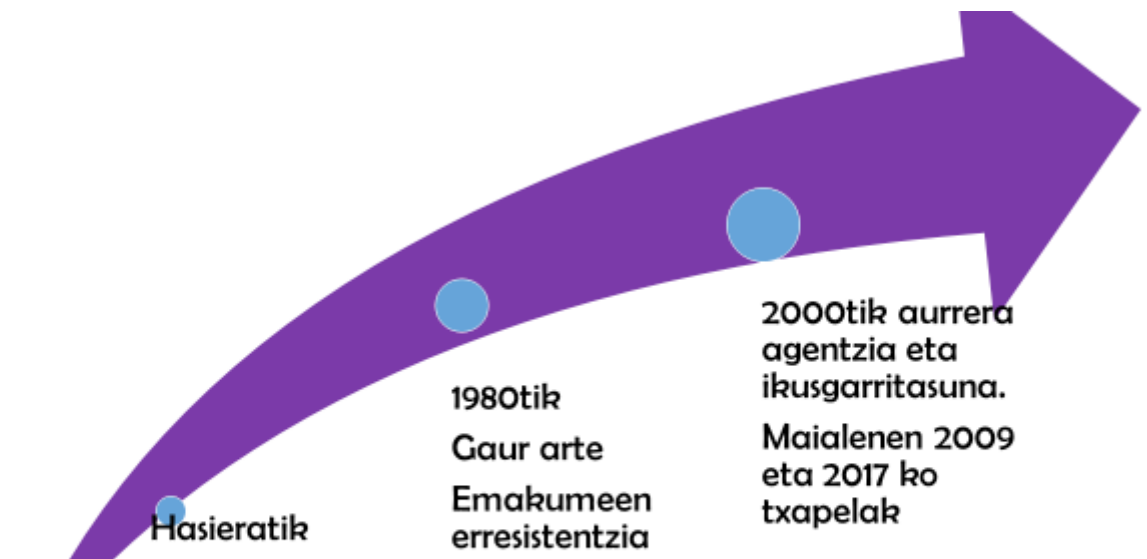

1980 bitarte

gizonezkoen

ikusgarritasuna

Iturria: egileak egina Murgialday

(2013) kontuan izanda

1. irudia. Emakume bertsolarien ahalduntzearen historia laburtua.

Ahalduntzeak desahaldunduen taldeetan boterea irabaztearekin zerikusia du (Kabeer, 1999; Murgialday, 2013). Zentzu horretan Lukesek (1974) planteatzen dituen boterearen hiru egoerak oso interesgarriak dira emakume bertsolarien historia kontatzeko. Botereak hiru aurpegi erakusten ditu: ikusten den boterea, ezkutuko boterea eta ikusten ez dena (León 1999; Murgialday 2013). Ikusten den boterea adierazpen formalez baliatzen da, jendarteak dituen erakunde eta jokoarauez. Hainbat pertsonak edo taldek beste talde edo pertsonek beren nahien kontra egin dezaten erabiltzen dituzten trebetasun eta gaitasunetan antzematen da botere hau. Emakume bertsolarien historian negartiak edo erostariak ezagutzera eman ditugu hasieran, eta esan behar da agintari politikoek nahiz erlijiosoek ahaleginak egin zituztela isilarazteko (Ugalde, 2018). Isilarazte hori legea eskuan egiten zuten. Boterearen bigarren aurpegia botere ezkutua da, zeinak bereak dituen ahots subalternoak (Spivack,1993) ikusezin bihurtzeko arauak eta prozedurak (desinformazioa, larderia erabiltzea, indarkeria beldurtzeko). Horrela, erabakietan zer irizpide hartzen diren kontuan eta zein ez zedarrituko da. Adibide gisa, historia egiteko orduan zer kontatzen den eta zer ez. Nola kontatzen den, zeintzuk diren protagonista. Eta azkenik, ikusten ez den boterea dago: jendeak aldaketarako eduki dezakeen grina apaltzeko arauak eta praktikak indartzen dituen boterea. Hartaz, baztertutako taldeek apatia, esaneko izateko sentimendua eta errudun-sentimenduak barneratzen dituzte (Lukes in Murguialday, 2006). Emakumeen lehen hitza literaturan garai batean barkamena eskatzea izaten zen, eta gaur egun ere, desenkusaka aritzea oso ohiko da emakumeongan. Emakumeok aipatu berri diren lehen bi botereparadigmen subjektu subordinatuak gara, genero-asimetria betikotzen duten kudeaketa politiko eta ekonomikorako sarbideak ukatu edo mugatzen zaizkigulako. Baina hori bezain kaltegarria da hirugarrena; gizonen nagusitasuna (Bourdieu, 2000) 
ezkutatzeko eta emakume eta gizonezkoen gatazkak gutxitzeko balioen, arauen eta praktiken barneratze subjektiboak duen paper murriztaileagatik.

Hiru botere moduei aurre egiteko eta desahalduntzeari nahiz bazterketari oldartzeko hainbat estrategia planteatzen dira (Murgialday, 2013). Izan ere, Foucaultek dioen bezala, boterea ez da jabetzan eduki daitekeen zerbait estatikoa, boterearen bidez eragiten da giza ekintza eta harremanen amaraunean. Jendartea existitzen den lekuan botere-harremanak daude. Beraz, horietan konfrontazioak, gatazkak, erresistentziak daude (Fernández, 2012; Murguialday, 2013). Estebanek (2011) ondo dioen lez, boteregune hauetan aldaketarako beharra ikusten da eta emakumeek, hain zuzen, Julianok $(1992,1998)$ esan bezala, ez dute biktimaren papera hartzen, aurre-egitearena baizik. Ez daude beste inork salbatzearen zain (Blandón, Murguialday eta Vázquez 2011).

Horrela, ikusgarri den botereari aurre egiteko eta errealitatea aldatzeko, boterea irabazi beharra ikusten da. Botere era horrek agency kontzeptuarekin du zerikusia. Objektu diren ahotsak eta pertsonak subjektu bihurtzearekin. Agentzia taldean edo bakarka landu daiteke eta negoziazio, manipulazio, subertsio edo erresistentzia moduan ager daiteke. Adiera hori Ortnerek (2006) erabiltzen duen kontzeptua da eta gure egiten dugu. Beraz, agentzia ekintza soziala da eta horrela ulertzen dugu artikulu honetan. Hori esanda, ahalduntze-bidean, lehenik, agentzia lortu behar da, boterearen subjektu bihurtu alegia. Azken hamarkadetako ahalduntze kontzeptu ligthen aurrean argi utzi behar da norberak bere burua ahaldundu behar duela eta horretarako lehenik agentzia lortu behar duela (Mosedale, 2005). Ahalduntzea oso gutxitan erabiltzen den hitza da lehendik boterea duten pertsonez hitz egiteko. Batez ere pobre, baztertu, desahaldundu eta marjinatuez hitz egiteko erabiltzen da (Rowlands, 1997). Emakumeek izan behar dute euren ahalduntzearen subjektuak eta agentziarik gabe ez dago ahalduntzerik. Kasu honetan emakume bertsolariak dira euren ahalduntzearen agenteak. Genero-asimetriatik berdintasun egoera batera egindako garapena da ahalduntze-prozesua (Malhotra, 2015).

Gorago botereari aurre egiteko aipatu ditugun estrategiak kontuan harturik, estreinakoz, emakume bertsolarien barne-boterea hartzea gertatzen da, bazterketaren kontzientzia; bigarrenik, kontzientzia hori modu kolektiboan plazaratzen, kanporatzen, konpartitzen jakitea. Hitz batean, botere hori saretzen, talde-boterea bihurtzen jakitea (Mosedale, 2005). Eta azkenik, boterea irabazi eta boterearekin aurrez aurre jartzea (Kabeer, 1999). Kabeerrek (1999), bestalde, agentzia irabazi den neurtzeko hiru esparru aipatzen ditu eta hirurak interesgarriak dira bertsolarien ahalduntze-prozesua kalifikatzeko. Lehena, erabakiguneetan parte hartzea. Hemen ez da bakarrik inportantea erabakitzeko gaitasuna, oso inportantea da ere zeren inguruan eta non erabakitzen den. Bigarrenik, lekutzeak, horiek ere botere- edo subalternitate-lekuak bihurtzen dira. Badaude emakumeentzat leku debekatuak edota komeni ez direnak. Kabeerrek (1999), azkenik, indarkeria matxistarekin zerikusia duten datuak agentziarekin lotzen ditu: «Las mujeres de mayor edad, con hijos varones, con nivel educativo o que aportan ingresos al hogar tienen menor probabilidad de violencia que las jóvenes, sin hijos varones, educación e ingresos» (Murgialday 2006: 27). 
Botere hegemonikoari aurre egitean ainguratu badugu emakume bertsolarien historia irakurtzeko proposamena, Showalterrek (1983) bestalde, beste hiru aldi aipatzen ditu kultur analisietan emakumeen ikusgarritasuna behatzeko. Horiek ere lagungarriak dira emakume bertsolarien historia ikusgarri bihurtzeko. Showalterrek diosku emakumeak literaturan hiru etapa bizi izan dituela, 1840tik 80ra bitartean gizonak emulatzen; 1840-1920ko tartea euren espazioa aldarrikatzen, aldi feminista izenekoa; eta azkenik, 1920tik gaur arte, bere estiloa propioa sortu duten emakumeen aldia.

\section{Emakume bertsolariei izena jartzen}

Emakume bertsolarien historia osatzeko, Joxerra Gartziak (2012) eginiko historia laburtuan azaltzen duen emakume bakarrari beste batzuk erantsi dizkiogu (ikus 1 . taula). Gartziak bertsolaritza irakurtzeko kronograma interesgarria eskaintzen du (ikus 1. irudia) Guk, ordea, ahalduntze-paradigmatik beste irakurketa proposamen bat egin dugu. Horretarako emakumeei izenak jarri dizkiegu eta bisibilizatu ditugu. Oraindik orain, ordea, lana dago izen zirenak berreskuratzeko (ikus 2. irudia eta 1. taula).

\begin{tabular}{|c|c|c|c|}
\hline & $\begin{array}{l}\text { Aldia } \\
\text { Período } \\
\text { Period }\end{array}$ & $\begin{array}{l}\text { Urteak } \\
\text { Años } \\
\text { Years }\end{array}$ & $\begin{array}{l}\text { Bertsolariak } \\
\text { Bertsolaris } \\
\text { Bertsolaris }\end{array}$ \\
\hline & $\begin{array}{l}\text { Historiaurrea } \\
\text { Prehistoria } \\
\text { Prehistory }\end{array}$ & $\begin{array}{l}\text { Hasieratik } 1800 \text {. urtera arte } \\
\text { Desde los orígenes hasta } 1800 \\
\text { From its origins to } 1800\end{array}$ & \\
\hline & $\begin{array}{l}\text { Desafioak eta bertsopaperak } \\
\text { Desafios y bertsopaperak } \\
\text { Challenges and bertsopaperak }\end{array}$ & $\begin{array}{l}\text { XIX. mendea } \\
\text { Siglo XIX } \\
\text { Nineteenth century }\end{array}$ & $\begin{array}{l}\text { Pernando Amezketarra, Etxahun, } \\
\text { Xenpelar, Iparragirre, Bilintx, } \\
\text { Otaño... }\end{array}$ \\
\hline 1 & $\begin{array}{l}\text { Bazterreko bertsolaritzatik lehenengo } \\
\text { txapelketetara arte } \\
\text { Del bertsolarismo marginal a los primeros } \\
\text { campeonatos } \\
\text { From marginal bertsolaritza to the first } \\
\text { championships }\end{array}$ & 1900-1935 & Txirrita, Kepa Enbeita \\
\hline 2 & $\begin{array}{l}\text { Isiltasun aldia } \\
\text { Tiempo de silencio } \\
\text { The time of silence }\end{array}$ & $1936-1945$ & \\
\hline 3 & $\begin{array}{l}\text { Biziraupen bertsolaritza } \\
\text { Bertsolarismo de supervivencia } \\
\text { Survival Bertsolaritza }\end{array}$ & $1945-1960$ & $\begin{array}{l}\text { Basarri, Uztapide, Lasarte, } \\
\text { Joxe Lizaso, Agirre, Lazkano, } \\
\text { Lazkao Txiki, Mattin, Xalbador... }\end{array}$ \\
\hline 4 & $\begin{array}{l}\text { Erresistentzia bertsolaritza } \\
\text { Bertsolarismo de resistencia } \\
\text { Resistance Bertsolaritza }\end{array}$ & 1960-1979 & $\begin{array}{l}\text { Azpillaga, Lopategi, Uztapide, } \\
\text { Basarri, J. Lizaso, Agirre, Lazkano, } \\
\text { Lazkao Txiki, Mattin, Xalbador... }\end{array}$ \\
\hline 5 & $\begin{array}{l}\text { Herriari kantatzetik publikoarentzat kantatzera } \\
\text { De cantar al pueblo a cantar para el público } \\
\text { From singing to the people to signing for } \\
\text { the people }\end{array}$ & $1980-1998$ & $\begin{array}{l}\text { Amuriza, Egaña, Sarasua, } \\
\text { Peñagarikano, Murua, } \\
\text { Mendizabal, Sebastian Lizaso... }\end{array}$ \\
\hline 6 & $\begin{array}{l}\text { Bertsolaritza multipolarra } \\
\text { Bertsolarismo multipolar } \\
\text { Multipolar bertsolaritza }\end{array}$ & 1999- & $\begin{array}{l}\text { Maialen Lujanbio, Unai Iturriaga, } \\
\text { Igor Elortza, Jeus Mari Iraza, } \\
\text { Amets Arzallus... }\end{array}$ \\
\hline
\end{tabular}

2. irudia. Bertsolaritzaren historia laburtua. Iturria: Joxerra Gartzia (2012: 51). 
1. taula. Bertsolarien historia laburtuan emakumeak bistarazten.

\begin{tabular}{|c|c|c|c|c|}
\hline & Aldia & Urteak & Gizonezkoak & Emakumeak \\
\hline 1 & Historiaurrea & $\begin{array}{l}\text { Hasieratik } \\
\text { 1800. urte arte }\end{array}$ & & $\begin{array}{l}\text { Sancha de Ozaeta, la joven de Lastur, } \\
\text { Sancha Hortiz [de Oro], Usoa de Alos, } \\
\text { Joana de Butrón, la dama de Irigarai, } \\
\text { María Antonia Soloaga, } \\
\text { Antonia de Zabala, Ángela de Armona, } \\
\text { Ana María de Gorostieta, Teresa Antonia } \\
\text { de Beobide, Concepción de Irazuzta, } \\
\text { María Magdalena de Lertxundi y María } \\
\text { Antonia de Etxeberria. }\end{array}$ \\
\hline 2 & $\begin{array}{l}\text { Desafioak eta "bertso } \\
\text { paperak" }\end{array}$ & XIX. mendea & $\begin{array}{l}\text { Fernando } \\
\text { Amezketarra, } \\
\text { Etxahun, } \\
\text { Xenpelar, } \\
\text { Iparragirre, } \\
\text { Bilintx, Otaño, }\end{array}$ & $\begin{array}{l}\text { Vicenta Mogel, Marieder Uthurralt, } \\
\text { Marie Louise Osorio, Josefa de } \\
\text { Hondarribia, la "marquesa" de Larrume, } \\
\text { María Luisa Petriarena, Sabina Elizegi, } \\
\text { Marie Argain, Marie Anne Etchegaray, } \\
\text { Juana Josefa Bengoetxea, Josefa Antonia } \\
\text { Aranberri, Josefa Zubeldia, Plácida } \\
\text { Otaño, Josefa Ignacia Azkune. }\end{array}$ \\
\hline 3 & $\begin{array}{l}\text { Bazterreko } \\
\text { bertsolaritzatik } \\
\text { lehenengo } \\
\text { txapelketetara bitarte }\end{array}$ & $1900-1935$ & $\begin{array}{l}\text { Txirrita, Kepa } \\
\text { Enbeita }\end{array}$ & Marcelina Lopetegi, Lucasia Elizegi, \\
\hline 4 & Isialtasun aldia & $1936-1945$ & & Sor Justina Aldalur, Sor Niño Dios, \\
\hline 5 & $\begin{array}{l}\text { Biziraupen } \\
\text { bertsolaritza }\end{array}$ & $1945-1960$ & $\begin{array}{l}\text { Basarri, Uztapide, } \\
\text { Lasarte, Joxe } \\
\text { Lizaso, Agirre, } \\
\text { Lazkano, Lazkao } \\
\text { Txiki, Mattin, } \\
\text { Xalbador... }\end{array}$ & Mari Treku, Lucía Goñi, Ignacia Etxabe, \\
\hline 6 & $\begin{array}{l}\text { Errresistentzia } \\
\text { bertsolaritza }\end{array}$ & $1960-1979$ & $\begin{array}{l}\text { Azpillaga, } \\
\text { Lopategi, } \\
\text { Uztapide, Basarri, } \\
\text { J. Lizaso, Agirre, } \\
\text { Lazkano, Lazkao } \\
\text { Txiki, Mattin, } \\
\text { Xalbador }\end{array}$ & $\begin{array}{l}\text { Mari Xan Minaberry, Lucía Goñi, } \\
\text { Ignacia Etxabe, }\end{array}$ \\
\hline 7 & $\begin{array}{l}\text { Herriari kantatzetik } \\
\text { publikoari kantatzera }\end{array}$ & $1980-1998$ & $\begin{array}{l}\text { Amuriza, Egaña, } \\
\text { Sarasua, } \\
\text { Peñagarikano, } \\
\text { Murua, } \\
\text { Mendizabal, } \\
\text { Sebastian } \\
\text { Lizaso... }\end{array}$ & $\begin{array}{l}\text { Germantxa Iñarga-Daubas, Cristina } \\
\text { Mardaras, Arantzazu Loidi, Iratxe Ibarra, } \\
\text { Estitxu Arozena, Maialen Lujambio, } \\
\text { Nerea Elustondo, Amaia Agirre, }\end{array}$ \\
\hline 8 & $\begin{array}{l}\text { Bertsolaritza } \\
\text { multipolarra }\end{array}$ & $1999-\ldots$ & $\begin{array}{l}\text { Unai Iturriaga, } \\
\text { Igor Elortza, Jesus } \\
\text { Mari Irazu }\end{array}$ & $\begin{array}{l}\text { Maialen Lujanbio, Alaia Martín, Uxue } \\
\text { Alberdi, Ohiana Baltra, Onintza Enbeita, } \\
\text { Oihane Perea... }\end{array}$ \\
\hline
\end{tabular}

Iturria: Joxerra Gartzia (2012) oinarrian hartuta, Anaisabel Ugaldek atondua. 


\section{Helburuak}

Lan honen helburu nagusia marko teorikoaz nahiz enpirikoaz baliatuta, emakume bertsolarien historia ulertzeko eta ezagutzeko proposamenak egitea izan da. Horretarako hiru helburu zehatz izan ditugu.

1) Gaur egun bertsotan ari diren emakumeen kopurua ezagutu, haien profila aztertu eta ahalduntze-prozesuan kokatzen jakitea.

2) Garai bateko emakume bertsolarien izenak berreskuratzea datu-baseak behatuz eta bertsolariak eta adituak galdetuz

3) Egungo bertsolarien ahotik aurreko bertsolarien historia kontatzea.

\section{Metodologia}

Bi metodologia uztartu ditugu, batetik kuantitatiboa, horrela $200^{2}$ bertsolari emakumeengana iritsi nahi izan dugu galdetegi baten bidez modu azkar eta zabalean haien profilaren datu batzuk jasotzeko. Bestetik, behin emaitzak eskuan, 25 bertsolari eta aditurekin izan gara eta jakin nahi izan dugu nola ikusten eta ezagutzen duten aurreko bertsolarien historia. Horretarako 5 eztabaida-talde eta 5 kontakizun edo errelato bildu ditugu.

\subsection{Partaideak ${ }^{3}$}

2. taula. Partaideen kopuruak.

\begin{tabular}{|l|c|c|c|c|}
\hline $\begin{array}{c}\text { Partaideen } \\
\text { izaera }\end{array}$ & $\begin{array}{c}\text { Partaide } \\
\text { kopuru osoa }\end{array}$ & Emakumeak & Gizonak & $\begin{array}{c}\text { Zehaztu } \\
\text { gabekoak }\end{array}$ \\
\hline Bertsolaria & 7 & 7 & 0 & 0 \\
\hline Bertsozalea & 1 & 1 & 0 & 0 \\
\hline Gai-jartzailea & 1 & 1 & 0 & 0 \\
\hline Ikertzailea & 2 & 2 & 0 & 0 \\
\hline Bertsolari gaztea & 11 & 8 & 3 & 0 \\
\hline Genero Taldekoa & 3 & 2 & 1 & 0 \\
\hline
\end{tabular}

2. Ikerketa hau EHU/UPVko IKhezi ikerketa-taldeak egin du eta ikerketaren lanik zailena egun kantuan ari diren 200 bertsolariak zein diren antzematea izan da; izan ere, datu-baseak errespetatuz egin baita lan hau. Denetara 200 bertsolari egun kantuan ari direnak topatu dira eta horiekin osatu da lehen galdetegia.

3. Partaideak modu zehaztuan azaltzen dira Lasarte et al. (2016) liburuan, baina hemen taulak errepikatzea deliberatu da; izan ere, ikerketa argiago geratzen da ikerketako corpusa zehaztuta. 4 urtez ikertzen aritu bagara ere, corpusa ez da aldatu. 
3. taula. Partaideen kopuruak tresnen arabera.

\begin{tabular}{|l|c|c|c|c|}
\hline \multicolumn{1}{|c|}{ Tresna } & $\begin{array}{c}\text { Partaide } \\
\text { kopuru osoa }\end{array}$ & Emakumeak & Gizonak & $\begin{array}{c}\text { Zehaztu } \\
\text { gabea }\end{array}$ \\
\hline ET1 & 3 & 3 & 0 & 0 \\
\hline ET2 & 5 & 5 & 0 & 0 \\
\hline ET3 & 6 & 3 & 3 & 0 \\
\hline ET4 & 4 & 4 & 0 & 0 \\
\hline ET5 & 3 & 2 & 1 & 0 \\
\hline Errelatoak & 5 & 5 & 0 & 0 \\
\hline
\end{tabular}

Eztabaida-taldeak ET1, ET2, ET3, ET4 eta ET5 kodeekin izenpetu dira; errelatoak, Er1, Er2, Er3, Er4 eta Er5; generoaren bereizketa, ostera, G, gizonezkoarentzat, eta $\mathrm{E}$, emakumezkoarentzat.

4. taula. Galdetegian parte hartutako partaideen kopuruak adinaren arabera banatuta.

\begin{tabular}{|l|c|c|c|}
\hline Partaideen izaera & Partaide kopuru osoa & Emakumeak & Gizonak \\
\hline $\begin{array}{l}18 \text { urte baino } \\
\text { gutxiago }\end{array}$ & 21 & 21 & 0 \\
\hline $19-25$ urte & 40 & 40 & 0 \\
\hline $26-40$ urte & 37 & 37 & 0 \\
\hline $41-51$ urte & 4 & 4 & 0 \\
\hline 60 baino gehiago & 1 & 1 & 0 \\
\hline Zehaztu gabekoak & 18 & 18 & 0 \\
\hline
\end{tabular}

\subsection{Informazioa biltzeko erabili diren tresnak}

Informazioa biltzeko erabili diren tresnak honako hauek izan dira: eztabaidataldeak, haien transkripzioa; errelatoak, eta galdetegia.

\subsubsection{Eztabaida-taldeak}

Eztabaida-taldeak, funtsean, taldeko elkarrizketak dira. Elkarrizketa sakonen ezaugarriak dituzte, baina pertsona bat baino gehiago elkartzen dira solasaldian. Gai jakin bati buruz mintzatu bitartean, elkarrizketatuen iritzi ezberdinak kontrastean jartzean datza focus group hauen izatea, betiere, iritziak, sentimenduak eta kontraesanak jasotzen direlarik. Gure kasuan, emakume bertsolarien historia izan da mintzagaia. Era horretan, aurretik jarritako helburuen erantzunak bilatu nahi dira planteamendu komunikatibo eta dialogikoen bidez (Freire, 1999; Habermas, 1994; Aubert, García, eta Racionero, 2009). 
Eztabaida guztietan moderatzaileak elkarrizketaren bidez elkarrekiko begirunea eta gaiarekiko hobekuntza lortu nahi dela jakinaraziko du (Limon eta Crespo, 2002). Izan ere, Rapley-k (2014) dioen moduan, datuak metatzea helburutzat duen focus group batean ez dago behin betiko erantzunik, ezpada horiek testuinguruaren eta beste solaskideekiko adierazpenen arabera esanahiaz betetzen doazela.

\subsubsection{Errelatoak}

Hainbat partaide ez dira etorri eztabaida-taldeetara zenbait arrazoi direla medio, kasu batzuetan ez zutelako bere burua agerian utzi nahi beste jende baten aurrean, edota bestelako eginbeharrak gorabehera ezinezkoa izan dutelako eztabaidetan parte hartu. Ikerketa-teknika hau ikerketa autobiografikoan erabilia izan da (Bolivar, \& Domingo, 2006), teknika honen bidez, ideiak eta iritziak azal daitezke oztoporik gabe. Hausnarketak sakonagoak dira, baina bat-batekotasuna galtzen da, hala ere jaso daitezkeen testigantzak oso baliotsuak izan daitezke.

\subsubsection{Galdetegiak}

Galdetegia Interneten bidez helarazi zaie emakume bertsolariei. Baiezkoa edota galdetegiari erantzuteko baimena eman dutenei inkesta helarazi zaie. Google Forms aplikazioa erabili da galdetegia bidaltzeko. Datuen antolaketaren azkeneko fasean, SPSS.22 aplikazioa erabili da informazio adierazgarriena erantzunetatik atera eta kategorietan nahiz azpikategorietan sailkatzeko. Inkesta kuantitatibo hau ikerketaren bigarren fasean erabili da.

Ikerketa kualitatiboaren tresnatzat hartzen diren elkarrizketa sakonak nahiz focus group-ak beste faseetan erabili dira ikerketa honetan. Artikulu honek ikerketaren atal bat jasotzen du, hain zuzen ere, sistema kategorialean zehazten den gaiari dagokiona. Baina arestian esan bezala, galdetegi kuantitatiboaz gain, kualitatiboa ere erabili da. Inkesta kualitatiboen helburua honako hau izan daiteke: erantzuten duten pertsonek zenbateraino dituzten antzeko sinesmenak jakitea, antzeko portaerak edota antzeko diskurtsoak zedarritzea. Esan beharra dago galdera berak egin zaizkiela pertsona guztiei; hau da, ikerketan parte hartu duten bertsolari, bertsozale, gai-jartzaile eta elkartekideei kontu berak itaundu zaizkie. Hala jokatu izanak erantzunak kuantifikatzeko modua eman digu (Vizcarra, Macazaga eta Rekalde, 2009).

\subsection{Informazioa tratatzeko erabili den prozedura}

Informazioaren analisia, elkarrizketa eta galdetegiak pasatzearekin batera, ikerketaren atalik esanguratsuena da (Goetz eta Lecompte, 1988). Informazioaren azterketa funtsean modu induktiboan, dinamikoan eta sistematikoan egiten da. Horrela, jasotako iritzien ezagutza, aukeratzea, sailkatzea, alderatzea eta interpretazioa egiten da. Prozesu honi esker, jasotako informaziotik ideia nagusiak atera dira (dimentsioak, kategoriak), eta horietan barne sortzen diren azpigaiak (Rodríguez, Gil eta García, 1996; Coffey eta Atkinson, 2003 in Lasarte et al., 2016). Informazioa kategorizatu ostean, sistema kategorialaren bidez erantzunak antolatu eta ordenatu dira. Kategoria-sistema horren arabera informazioa tratatu ahal izan da. Hala sistema kategorialaren dimentsioak honako hauek dira (ikusi 5. taula). 
- Lehen dimentsioan jasotzen eta interpretatzen diren emaitzak elkarrizketatuek perspektiba historikoa sartu eta garaiak edo belaunaldiei buruz esaten dituztenen gainekoak dira. Horrela, aztergai izan ditugun subjektuek bertsolaritzaren historian dituzten ezagutzak antzemateko balio izan du lehen dimentsio honek.

Esan bezala, ahotsak biltzen dituzten dokumentuak kategoriatan sailkatu dira. Hau guztia burutzeko beherago duzuen sistema kategoriala (5. taula) baliatu dugu analisia egiteko. Bertan, erdietsitako datuak sailkatzeko dimentsio ezberdinak erabili dira eta emaitzak NVIVO11ren bidez tratatu ondoren, interpretatu dira.

5. taula. Lehen dimentsioa eta kategoriak.

\begin{tabular}{|l|l|}
\hline \multicolumn{1}{|c|}{ Dimentsioak } & \multicolumn{1}{c|}{ Kategoriak } \\
\hline 1.-Emakume bertsolariak historian zehar: & 1.1. Aitzindariak \\
\cline { 2 - 2 } $\begin{array}{l}\text { Perspektiba historikoa sartzen denean eta } \\
\text { garaiak edo belaunaldiei buruzkoak esaten }\end{array}$ & 1.2. Belaunaldiak, garaiak, korronteak \\
\cline { 2 - 2 } dituztenean & 1.3. Ekarpenak, aitortzak \\
\hline
\end{tabular}

\section{Emaitzak}

Emaitzei dagokienez, bi atal bereizi dira. Lehenik eta behin, lehen partean modu kuantitatiboan egungo bertsolarien profila landu $\mathrm{da}^{4}$, eta, bigarren atalean, modu kualitatiboan historian ezagutzen dituzten bertsolariez jasotakoa adierazi da.

\subsection{Gaurko emakume bertsolarien profilaren zertzelada batzuk}

Adina, bukaturiko ikasketak eta ogibidea izan dira kontuan hartu diren datu soziodemografikoak. 200 elkarrizketatuetatik 121 emakumek erantzun dute: horietarik $\%$ 20,4 18 urte baino gutxiagokoak dira, \% 38,8 19-25 urte-bitartekoak; \% 35,9 26-40 urte-bitartekoak eta \% 3,9 41-59 bitarteko adin-taldekoak. Bigarrenik, bukatutako ikasketen inguruan, laginaren ia erdiak $(\% 49,6)$ unibertsitateko ikasketak ditu; \% 27,4k Batxilergoko ikasketak eta \% 11,1ek Bigarren Hezkuntzan dihardu. Ogibideari dagokionez, 106 emakumeren lanbideak jaso dira: \% 29,8 ikasleak dira, $\%$ 20,7 irakaskuntza-munduan dihardu, eta, beste lanbideen artean, bertsolaritzairakasleak $(\% 1,7)$, idazleak $(\% 0,8)$, ikasle eta tarteka aisialdiko hezitzaileak $(\% 0,8)$, eta Bertsozale Elkarteko eragile eta irakasleak $(\% 0,8)$ aurki daitezke. 30 emakumek ez dute lanbidea aipatu (Lasarte et al., 2016).

4. Ikerketaren parte hau Lasarte et al. ( 2016) Emakume bertsolariak. Ahanzturatik diskurtso propiora liburuan argitaratu eta modu zehatzean agertzen da. Zati honetan datuak laburtu ditugu, horrela, alde kualitatiboarekin triangelukatu eta marko teorikoan aipaturiko ahalduntze-estrategiak zehaztu ahal izateko. 


\subsection{Emakume bertsolariak historian zehar ${ }^{5}$ edo zer ezagutzen duten historia horren inguruan gaurko emakume bertsolariek}

Gaur egungo bertsolaritzan izan den iraultzarik handienetarikoa emakumeak plazan normaltasunaz ikustea izan da. Baina ikuste hori ez da bat-batekoa izan, aurretik ere izan direlako bertsotan, koplatan egin zuten andreak. Hori da, hain zuzen ere, galdetu zaiena, ea zeintzuk izan diren euren aitzindari eta erreferente, bereizten dituzten belaunaldiak eta korronteak.

\subsubsection{Aitzindariak}

Gaur egungo emakume bertsolariei, emakume bertsolariak denboraren joanean kokatzeko asmoz, aitzindarien inguruan galdetu genien eta erantzunak denetarikoak izan dira. Adina, noski, faktore inportante bat da aurrekarien ezagutzan. Izan ere, gazte gehienentzat aitzindariak dira eurak baino urte batzuk lehenago plazara salto egin zuten neska bertsolari ezagunak, eredutzat dauzkatenak. Eta zaharragoak, ordea, denboran urrutiago doaz eta prentsak edo akademiak bistaratutakoaren berri ere badute. Eta idatziz erantzun dutenen artean aurrekarien informazioa da, hain zuzen, osatuena, nahiz eta onartzen duten ezjakintasun handia dagoela, ikertu beharra. Baina nola egin lan hori? Hala diote:

Garai ilunagoetatik gatozela jakin badakit. Horregatik bertsolaritzaren historian (azken ehun eta berrogei urte, demagun) emakume bertsolarien aztarnak nekez aurkitzen dira. Arkeologia lan ikaragarria egin behar da hori guztia argitzeko? (150306_Er2)

Hasteko, gutxi dakigu bilakaera horren inguruan. Oso gutxi. Datu eta informazioa falta da, bai kuantitatiboa, bai kualitatiboa. Pertsonalki uste dut (baina nire ustea da, besterik ez) emakumeak beti egon direla bertsolaritzan. (150306_Er1)

Ateratzen denean orain Asteasuko artxiboan 1770ean jaiotako bertsolariak, bertsotan egiten zutenak. Eta sexuari buruzko bertsoak dira, ez plazan kantatutakoak, etxeetan kantatutakoak. Orduan, emakumeak kantari beraien artean, horri ez zitzaion bertsolari deituko, baino bertsotan egiten zuten. (150212_ET4_E)

Profazadoretatik gaur eguneraino bertsolari eta emakume izan diren pertsonak ez dira gutxi izana, gutxi izan dira, ordea, erreferente eta erreferentzial. Bilatuz soilik aurki bailitezke emakume bertsolari haien testigantzak eta lekukotasunak. Joxepa Anttoni Aranberri Petrirena «Xenpelar» errenteriarra izan da patxadatsuen aztertu dudana. Bertsolari, langile eta iraultzailea izan zen, bere mundu txikiaren baitan. Bere bertsoak eta bere mezuak ausartak ziren eta bere emakumetasunak gune zentrala hartzen du bere obran behin baino gehiagotan. (150306_Er5_E)

Uste dut orain ari garela pixkanaka isilduak eta ahaztuak izan diren emakume bertsolariak erreskatatzen: Asteasun azaldu diren XVIII. mendeko emakume bertsolarien testigantzak, Joxepa Antoni Aranberri, Matea Joxepa Zubeldia... 1452ko Bizkaiko foru zaharretan debekatu egiten zitzaien kantatzea, gero isiltasun handi bat dago, ez dago haien bertsorik gordeta, apenas dakigun ezer izan zirenei buruz ...

5. Ikerketaren atal hau, alde kualitatiboa azaltzen duena, EHUko Mikel Laboa Katedrak eta Mintzola Fundazioak diruz lagundutako ikerketa argitaratu gabeko baten zatia da (ikus Bibliografian: Lasarte et al. (2014). 
Eta badirudi gaur egungo bertsolariak aurrekoen haririk gabe hasi ginela bertsotan, nahiz eta sinesten dudan badagoela hor hari ikusezin bat, aurrekoen esan-ezinetara eta ikusezintasunera lotzen gaituena. (150306_Er3_E)

Ume ginela inork ez zigun Bixenta Antonia Mogelez hitz egin; ezta Xenpelarren iloba bertsolari hartaz ere. Kristina Mardaras izeneko emakume bat txapelketan atera zela jakin genuen 1985an, baina ez genuen ezagutzen, ez ziguten haren pausu txikiaren garrantzia esplikatu. la 30 urte izango nituen Inaxi Etxabe elkarrizketatu nuenean, Berriarako. Ez dakit nola esplikatu: neure buruarekin haserre sentitu nintzen momento batez. Emakume hau beti hemen egon da, eta ez dut ezer jakin. (150306_Er4_E)

Aspaldiko andre bertsolarien gaineko ezagutza oso urria da bertso-munduan diharduten gazteenen artean. Horrela, neska bertsolari batek diosku berak unibertsitateko lan bati esker jakin zuela egon zirena, espazio publikoan andreek bertsotan egiten zutena, nahiz eta gaizki ikusita egon bere garaian eta ondoren ere.

Kontatu egingo dut, lehengo urtean unibertsitatean lan bat egin nuen emakume bertsolariei buruz, gehiago hori historikoki begiratuz, eta bai izan zela nik txikitatik jan dudan edo sinetsi izan dudan mito bat puskatzea. Niri beti esan didate ez direla izan emakume bertsolariak, espazio publikoan gaizki ikusiak zirelako eta ez dakit zer baina izan da deskubrimentu bat jakitea muga hoiek edukita ere baietz, egon, egon direla. Gauza bat dela ikusezinak bihurtu dituztela eta orduan guregana ez direla iritsi eta sinestarazi digutela ez direla egon. (150109_ET1_E)

XX. mendea aurrera zihoala hasi zirenen ausardia eta kemena azpimarratzen dituzte, gizonen munduan sartu zirelako. Arestian aipatutakoei beste izen batzuk gehituz gero, zerrenda luzea osatuko genuke aitzindariekin.

Garai horretan lortu zuten Maialen [Lujanbio] eta, Maialen bezala, Arantzazu Loidi. Nik Kristina [Mardaras]en erreferentzia ez nuen eduki umetan, gero izan dut, baina Arantzazu Loidi, Iratxe Ibarra ere gogoratzen naiz, Estitxu Arozena, bueno, momentu horretan tokatu ziren emakumek, ba beraien lorpena izan zela, ordu arte gizonena bakarrik zen munduan lortu zutela beraiek hor sartzea, ez?, zeintzuk sartu ziren, ez?, gizonena zen estandar horren barruan hainbeste txirriatuko ez zutenak, hainbeste... esan nahi dut momentu horretan ba zenbait emakume bertsolarik izugarri, disonantzi izugarria sortzen zuten, ez?, igual gaur aukera gehiago izango lituzkete iristeko, ez?, nahiko balukete, igual ez zuten izan nahi bertsolari baina, ... baina hor sartu ziren ba terreno maskulino horretan kabida izan zezaketenak, ez?, osea onartzen ziren eszepzio bezala, baina zen hainbesteko disgresio sortzen ez zutenak. (150223_ET5_E)

Kristina Mardarasen izena ekarri behar da gogora, txapelketa nagusi batean parte hartu zuen lehenengo emakumea delako, 1985ekoan oker ez banago. Bertsolaritzaren nagusitasuna esparru horretan neurtzen da, zalantzarik gabe. Horietako batean parte hartu zuelako gogoratzen dugu hain ederki haren ausardia eta kuraia. Bera baino lehenago bertsotan aritu diren beste batzuen izenak badakizkigu baino erreferenteak direnik ezin da esan, haien gainean ez baita ezer eraiki. Beste askoren izenak galduta daude burka efektua deitzen diodan estrategia ezabatzaileari esker. Mardarasekin batera Arantzazu Loidi aitzindari, eta berehala Estitxu Arozena, Iratxe Ibarra eta Maialen Lujanbio. Denak gaur-gaurkoak. (150306_Er2_E) 
Nik primeran gogoratzen dut emakume bertsolari bakoitza entzun-ikusi nuen lehen aldia. Umea nintzela, inpresioa egiten zidaten emakume haiek, miresgarriak iruditzen zitzaizkidan. Maialen Lujanbio Elgoibarko kiroldegian entzun nuen lehen aldiz, Ainhoa Agirreazaldegi Hitzetik Hortzera Joxe Agirrerekin ofiziotan, Oihane Enbeita ere Hitzetik Hortzera kartzelako bisitei buruzko bertso-idatzi batzuk kantatzen, Nerea Elustondo Zestoako frontoian, Alaitz Sarasola ere Hitzetik Hortzeran bertsoafari batean... Primeran gogoratzen ditut irudiak eta sortu zidaten inpresioa [...]. Uste dut emakume izate soilagatik ateratzen garela bertsolaritzaren ohiko moldetik, kanonetik. Lujanbiok egin duen bidea ikaragarria da, mirari bat, biziraupen eta eraldaketa-lan konstante bat. Xehetasunak, enpatia, txikira jotzea, ertzari begiratzea, emozioei leku egitea, begirada propio bat lantzea... (150306_Er3_E)

Bertsolari helduagoek aurrekarien gaineko beste era bateko aitortzak egin dituzte. Hala nola emakume bertsolariak gaitzat dauzkaten ikertzaileek, Jone Miren Hernández, Estitxu Izagirre edo Uxue Alberdik kasu; baita Itziar Izagirrek ere, Genero Taldean buru belarri ari denak. Bertsoen mikrokosmosetik at feminismoak edo artegintzak ere izan dutela eraginik eurengan baieztatu dute.

Bestela izandako ibilbidea gizartean gertatutakorekin batera joan da, nire ustez. Emakumeak esparru ezberdinetara joan dira heltzen eta bertsolaritza beste bat izan da. Hori bai, iruditzen zait euskal kulturaren unibertsoa kontuan hartuta bertsolaritzan izandako aldaketak nahiko nabarmenak eta azkarrak izan direla. Hori, nagusiki, emakumeen lorpena izan dela uste dut. Geroago gizonezkoek ere ikusi dute aldatzeko beharra baina emakumeak egon dira (eta daude egun ere) tiraka. (150306_Er1_E)

Belaunaldi berriaz ere mintzo dira, sortzen ari dena, bertsokera, estetika diferenteak eskainiz, beste emakume-irudi bat.

Eta gaur egun, Maialenek egin duen bezala, eboluzioa ikusten dut, horrea sartzen ari diren emakumek hasi direla edo ari direla esaten, bueno baina nik orain hemen nola egin nahi dut bertsotan, ez?, nola sartu nahi dut, inkluso aipatzen da, ez?, ba Uxue Alberdi, Alaia Martin, hauekin ere ari da sortzen beste emakume estereotipo bateri ere utzi zaio tokia bertsolaritzan, o, sea, hori izan da, ba bueno, ate zirrikitua pixka bat gehiago irekitzen ari da, ez? eta espero dezagun gero eta emakume anitzagoak sartzea eta sartzen ari dira, baina esan nahi dut gaur egun beste emakume horiek ere ba ekarri dute estetika izugarri femeninoa, ez? Ba, igual, beste muturra ekarri dute, oso propio gainera eta, bueno, ekarri du beste zerbait plazetara, ez? (150223_ET5_E)

Nik ikusten dudana da Kriston lana egiten ari direla horren atzean eta belaunaldi berri hori ere..., zeren bertsolaritzak daukan hori da, gazte jende asko ari dela sartzen edo, behintzat, zaletzen eta, ez dakit, nik uste dut belaunaldi berri horrek badakarrela ere beste pentsatzeko era bat eta azkenean, gizartearen isla bat denez, pentsatu nahi dut ere gazteak ba horren aldetik ba hobera doazela, ez dakit... (150131_ET2_E)

Bukatzeko eta laburpen gisa, bat datoz esaten dutenean kontakizuna egiteke dagoela, perspektiba falta zaiela bertsolaritza testuinguru historiko zabalago batean txertatzeko. Arrazoi dute. Historiaren ikuspuntua izango duten ikerketak falta dira, andre bertsolarien existentzia bera ere azaleratuko dutenak, ezkutuan baitago. Helduenek iraganeko bi muturrak ezagutzen dituzte: XV. mendean Bizkaiko Foru 
Zaharraren debekua jaso zutenak (iraingileak omen) eta 1900 inguruan jardun zutenak, tartean albiste izan diren XVIII. mendeko Asteasuko koplariak. Gazteagoek, jardunean ari direnen izenak bereziki. Edozein izanik arrazoia, ez bada iragana arakatzen, ezin aspaldiko aurrekaririk ezta erreferenterik ezagutu.

\section{6. taula. Aurrekariak.}

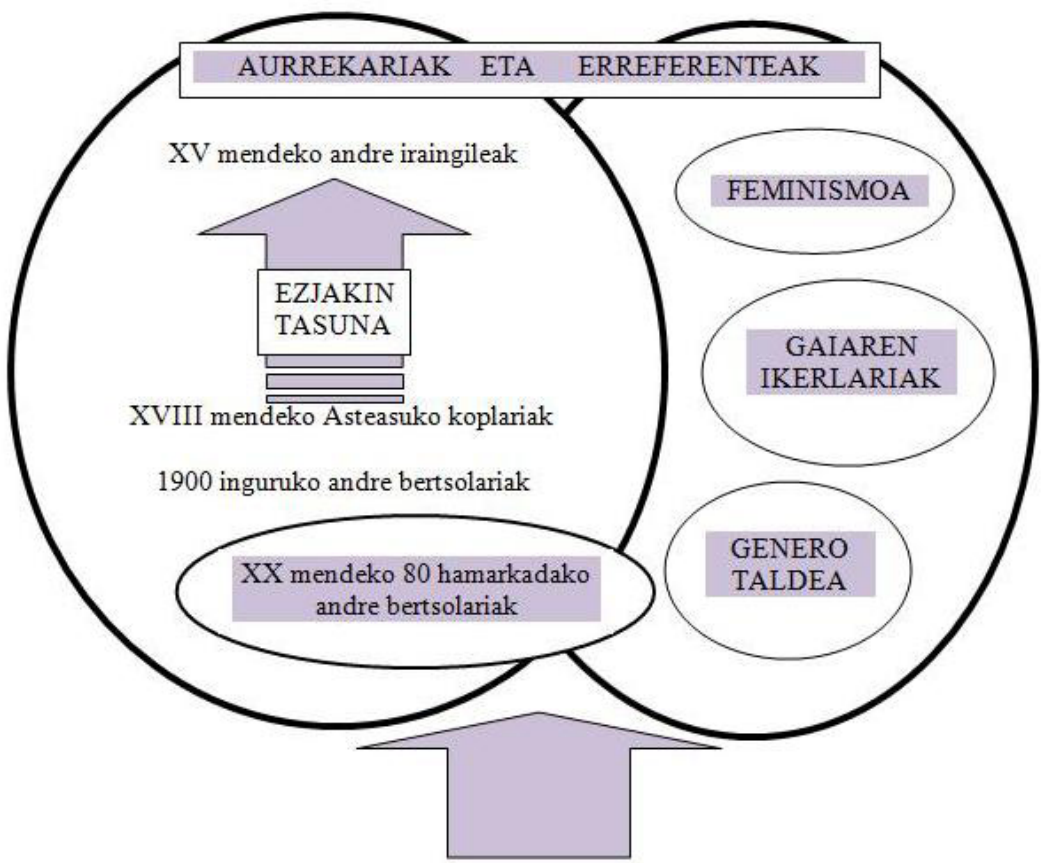

GAUR EGUN BERTSOTAN ARI DIREN EMAKUMEAK

HASI BERRI DIREN BERTSOLARIAK

MUTIL

BERTSOLARIAK

\subsubsection{Belaunaldiak, garaiak, korronteak}

Bada adostasuna emakume bertsolarien artean, batez ere plazaz plaza urteak daramatzatenen artean, bi belaunaldiren arteko etena zehaztean, hori bai, iragan hurbilenean. Aldaketa bertso-eskolen agertzeak ekarri ei zuen XX. mendeko 80 hamarkadaren inguruan. 
Lehena, aurrekoa, beste edozein arlotan bezain gogorra andre ziren heinean. Eta itxuraz, bideo bat ikusteak eragin zuen garai horren inguruan izan zuten pertzepzio ezkorra handitzeko, nahiz eta ez diren sentitzen emakume haien oinordeko.

Beste gai askotan bezala, ikusezintasuna, debekatutako ahotsak, bueno, espazio publikoan ez zeuden emakumeak eta ezezagutza bat, ez dudana benetan gehiegi sakondu, esan nahi dut zer suposatzen duen isildu den mundu oso bat ehunka urteetan eta gero Historiaren bigarren parte bat bertso-eskolak sortu zirenean [...] nik, egia esan, lehenbiziko zatiari buruz, ba bueno, ez dakit, ez dut feminismoak egin dezaken betiko Irakurketaz gain, ez dut, ez naiz gehiegi..., jarri [...] oso tristea, mingarria eta ez dakit, oso barrura iristen den gauza bat da (150109_ET1_E)

Nik ere, zuek bezala, oso garbi daukat etena, ba hori, Historia esaten dugunean, ba hori, zuk aipatzen dituzun emakume hoietaz eta isildutako eta bizipen hoietaz nik ere orain dela gutxi arte, egia esan, ia ia bertso eguneko bideo hartara arte ${ }^{6}$, o sea, egin genuen bideo hori, ez?, isildutako ahots eta aurpegi eta izen eta hori denak erakusteko, horrela gorputzean sentitu tristura hori, agian, ez nuen sentitu ordura arte... (150109_ET1_E)

Bigarrena, bertso-eskoletan ikasitakoak XX. mendeko 80ko hamarkadan hasi zirenak eta hainbat ezaugarri partekatzen zituztenak. Esaterako, Francoren ondorengo eskola mistoetan eta D ereduan ikasitakoak, unibertsitatera joateko aukera izan dutenak, etxetik kanpo lan egitea ezagutu dutenak, bizimodu urbanoagoa eta erosoagoa. Eta horrek guztiak zeharo hautsi ei zuen aurreko emakume bertsolariekin izan zezaketen lotura.

80 ko hamarkadatik aurrera etorri den... eta uste dut azken urteetan lanean gabiltzanean hortik berrikusi dugula Historia, ez?, zer gertatu zen benetan Historia berri honetan ba berdintasun batean edo hezitako Euskal Herri berri batean, Ikastolen mugimendua edo helduen kulturgintza, bueno, hor balio positibo asko zeuden eta gelditu zen oharkabean, bueno, ez ginela beharbada hain berdinak Historiak desberdin kokatu gintuenean, orduan, horren irakurketa egin izan dugu, nik uste dut azken urte hauetan, ezta?, eta hor sakondu dugu. (150109_ET1_E)

Gure aurreko emakumeek konpartitzen zituzten gauza batzuk, besterik gabe, ez genituela konpartitzen gure bizitzan, behintzat, bertso munduan genbiltzan emakumeok, zeren ere, hori ere esan behar da, bertso munduan gabiltzan emakumeok ezaugarri konkretu batzutakoak garela, normalean gara ia gehienok D eredukoak, asko guraso, bueno, biak lanean dabiltzanak, ikastoletakoak, ekonomikoki estatus bat, horrek danak ere eragin duela, ez?, eta esango nuke ezezagutza bat, bat-bateko haustura handi bat gure aurreko emakumeekiko. (150109_ET1_E)

Hamarkada bat beranduago, 1990ekoan, hasi ziren bertsolarienganako begirune osoz diote:

90eko hamarkada garrantzitsua izan zela uste dut, bertso-eskoletatik zetozen emakume gazte batzuk plazetara salto egin zutela, eta batzuek oraindik hor dirautelako. Haiei esker ikusi genuen guk, emakume izanda ere, bertsotan egin zitekeela, posible zela. Ordutik hona, emakumeak plazaratzen joan dira, baina ez agian espero zen proportzioan. Bertso-eskolek 30 urtetik gora daramaten arren martxan, plazan \% 20 baitira emakumeak. (150306_Er3_E)

6. Generoari dedikatu zitzaion Bertso Eguna (Informazio gehiago, Ibarzabal, 2015). 
Baita poza ere emakume bertsolari eskarmentudunaren ahotan, banakotasuna eta aniztasuna nabarmenduz:

Asko zabaldu da, hala ere, kantuan ari garen emakumeen abanikoa. Eta gauza batean egin dugu aurrera: gero eta gutxiago gara emakume bertsolarien kolektiboa eta gehiago gara pertsonak, bertsolariak, halako edo holako umorea dutenak [...] zaila da, niretzat, plazan gauden emakumeak definitzea. Bakoitzak bere berezitasunak ditu eta gero eta gehiago jabetu da jendea horretaz. (150306_Er4_E)

Gaur egungo belaunaldi edo adin-tarte desberdina dutenak bereizten dituzte, batez ere hasi berri diren gazteek; baita aldaketa-gogoa, kezka, gizonezko eta andrazko bertsolarien artekoa, behin baino gehiagotan komentatzen dute.

Bi belaunaldi desberdin daude oraindik, bi edo gehiago egon daitezke. (150131_ ET2_E)

Bai egon dela aldaketa handi bat, azkenean belaunaldi berri hori sortuta ia aldaketa handi bat dago, gutxienez konturatzen dena eta, gainera, aldaketa bat ere egon da ez bakarrik bertsozaleen aldetik, zeren eta bertsolarien aldetik ere egon da, o sea, bertsolari emakume aldetik eta bertsolari gizon batzuen aldetik ere bai. (150131_ET2_E)

Azkeneko hogei urte hauetako esperientzia edo niri bizitzea tokatu zaidana, pixka bat nago bien tarten, nik baneuzkan emakume erreferentek, baina gutxi, [...] eta azkeneko hogei urte hauetako «bum» honekin danakin daukat sentsazioa nik badauzkadala nire bizipenak, zuk edukiko dituzula zureak, berak bereak, diskurtso asko dagoela eta perspektiba falta zaigula. Asko, o sea, denoi. (150109_ET1_E)

Badago ardurarik gaur egun emakume bertsolarien inguruan egin beharrekoaz. Bateko eta besteko ideiak dituzte. Eragile aktiboak izan behar ote duten talde-kutsua mantentzen, belaunaldi berrien ideologizazioa dela-eta; eta, zer esanik ez, beldurra ere bai, teorizazioak ez ote duen bertsogintzaren kalitatea estaliko.

Konturatzeko bi modu daude, bizipenetik konturatzea edo teorikoki konturatzea, eta honekin nator hasieran esan dudanera, iruditzen zaidala gaur egun teorikoki aurreratuagoak gaudela esperientziatik baino [...] dagoela gazte jende pilo bat iruditzen zait [...] ideologizatua, sentsibilizatua, teorian oso aurreratua eta, gainera, gogo handiarekin eta esplotatzeko gogoarekin, baino, gazteak, bertsotan egin behar $\mathrm{da}, \mathrm{e}$ ?, hemen bertsotan egin behar da. Klaro! horrek gizartearentzako kriston balioa dauka noski, dudarik gabe, baino ari gara bertsotan egiteari buruz, bere maila guztietan, e?, baino bertsotan egiteari buruz ere bai eta hor ia beste parametro bat sartzen da, orduan konturatze hori ideologiatik edo konturatzea bizipenetik, bi gauza dira. (150212_ET4_E)

Argi dago bertsotan eginez ikasten dela, baina ikasketak, bertso-eskolak, lagungiroa, gizartea oro har, denak dira eragile inportanteak. Horregatik, garai bakoitzeko andre bertsolariek oso modu diferentean bizi izan dute euren bertso munduratzea.

XX. mendeko 80ko hamarkadara arte aritu zirenek erdi ezkutuan bete zuten euren bertsogintza, emakume izatea ere ezabatuta zegoelako orduko gizartean. Egoera politikoa, soziala eta kulturala aldatu zen, eta bertso-eskolen sorrerak izan 
zuen isla bertsolarien munduan. Han ikasi zuten neskek egin zuten lehenengo jauzia gizonenak ziren oholtzetara. Bide-urratzaile haientzat gogorra izan bazen ere, hurrengo hamarkadan etorri zirenentzat samurragoa izan da, bertsolari gizonezkoek eta publikoaren harrerak ere horrela eboluzionatu dutelako. Hartara, lehen rara avis zena, orain bat gehiago delako —edo izateko bidean delako- oholtzan edo plazan.

Belaunaldi berria ere badator bultzaka, aurrekoen lekukoa jasotzera. Beste momentu historiko batekoak dira eta dagokiena bete beharko dute.

\section{Ondorioak}

Beraz, emakume bertsolarien historian botere-gatazka etenik gabe gertatu den bezala, erresistentzia-prozesua eta agentzia-hartzea ere halaxe gertatu dira. 1980 bitartean emakumeak ikusezinak izan dira, botere androzentrikoa dela medio emakume bertsolariak isilduak eta batzuetan zigortuak ${ }^{7}$ izan dira. Esan daiteke, ordea, 1970-1980tik aurrera bertso-eskolei eskerrak eta emakumearen kontzientziaren hastapenei mugimendu feminista bide ${ }^{8}$, emakume bertsolariak erresistentzia eta agentzia modu bat sortzen hasten direla, horren ondorioz emakumeak kantuan ikusten eta emakume bertsolariak ikertzen hasten dira. Baina 2000 urte bitartean ezin hitz egin dezakegu boterea hartzeaz eta agentziaz; izan ere, Maialen Lujanbiok txapelak irabaztearekin batera baitatoz emakume bertsolarien arteko bilkurak, hitzaldiak, aldarriak (autora et al., 2016) eta Bertsozaleen Elkartean sorturiko Generoaren Batzordea (Erkiaga, 2008).

Lukesek (1974) proposatzen dituen hiru botere-paradigmen gainean aurkeztu dugun emakume bertsolarien historiarekin bat egin dute elkarrizketatuek, bestalde. Horrela, bertsolaritzaren bi aldiaz mintzo dira: protohistoriatik bertso-eskolak sortu arteko aldiaz eta hortik aurrerakoaz. Lehena, aldi androzentrikoa. Botere ezkutua (Lukes, 1974) gailendu eta emakume bertsolari aitzindariak ikusezin bihurtu zituen tenorea. Elkarrizketatutako bertsolarien hitzetan, Lukesek (1974) aipatzen zuen botere ezkutua zela medio, emakume bertsolarien ahotsak eta agerraldiak espazio publikoetan debekatuta zeuden.

Garai hori garai iluntzat dute. Bizkaiko Foru Zaharren 1452ko debekua aipatu dute besteak beste. Halere, garai horren inguruan galdetuta, informazioa eta perspektiba falta zaiela bertsolaritza testuinguru historiko zabalago batean txertatzeko aipatu dute. Historiak emakume bertsolariak ikusezinak bihurtu ditu. Arkeologia lana egitea ezinbestekoa ikusten dute emakume bertsolarien izenak erreskatatzeko. Bertsolari gazteenek plazan kantuan eurak baino lehenago hasitakoak aitzindaritzat dituzte; helduagoek izenak aipatzeko orduan, Joxepa Antoni Aranberri, Mattea Joxepa Zubeldia, Bixenta Antonia Mogel edota Iñaxi Etxabe izendatu dituzte batik bat.

Bigarren aldia, ikusgarritasunaren aldia, XX. mendeko 80ko hamarkadan bertsoeskolen sorrera eta emakume bertsolarien ikusgarritasunarekin kokatzen dute. Baina aldi horretan bi sasoi ezberdin bereizten dira Malhotrak (2015) definitzen duen ahalduntze-prozesuan. Lehenik, erresistentzia (Murgialday, 2013) garaiak aipatzen

7. Gehiago jakiteko (Ugalde et al., 2018).

8. Gehiago jakiteko (Epelde, Aranguren eta Retolaza). 
dira. Eta bigarrenik, agentzia (Ortner, 2006) garaia. Erresistentziaren tenorea modu askotara uler daiteke. Batzuek Arantzazu Loidi, Kristina Mardaras, Mailen Lujanbio, Estitxu Arozena eta Iratxe Ibarra aipatzen dituzte eta ausardia eta kemena egokitzen dizkiete. Garai haietan emakume horiek oholtzara igotzeak espazio publikoa hartzea ekarri zuen. Horren inguruan mintzo direla, ahalduntzeak (Kabeer, 1999) eragin duen disonantziaz dihardute. Beste batzuek hori egin ahal izateko "eszepzio" hitza aipatzen dute, hainbeste disgresio sortuko ez zuen salbuespenegoera. Salbuespen-egoera hori esplika daiteke Showalterrek (1983) aipatzen zuen maskulinitate hegemonikoak emulatzearen kontzeptuarekin.

Bisibilizazioa, ordea, erresistentziaren bidez botere-gatazka sortzetik letorke. Horrela, ahalduntze-prozesu honetan emakume ikertzaileak ikertzen (Carmen Larrañaga eta Jone Miren Hernández) eta bertsolariak hitzaldiak ematen eta euren egoeraren inguruan hitz egiten hasten dira (Ainhoa Agirreazaldegi edo Uxue Alberdi kasu). Showalterrek (1983) aipatzen zuen bigarren aroa dugu bertsolari horien aldarri-sasoi hau. Horretarako, emakume bertsolariek bertsoen mikrokosmosetik at feminismotik edan eta bisibilizazio-lana eta espazio-berreskuratzea aldarri izan dute. Hartara, emakume bertsolariek nahiz bertso-munduan zihardutenek erresistentzia bide, bertsoa eta generoaren humusa elikatu zuten, 90eko hamarkadan bertsoeskoletan prestatutako emakumeak bertsotan plazetan hasi ziren bitartean.

Tenore horrek bisibilizazioaren bigarren aldiarekin bat egiten du. Horrela, agentziaren sasoia nabarmentzen da azken bi hamarkadetan. Agentziaren garaian biziraupena eta eraldaketa lan konstante bat izan dira. Aldi horietan zehar kantuan aritu diren eta ari diren bertsolarien profila erabat aldatu da. 200 emakume bertsolari ari dira kantuan egun, horietarik \% 75ek D ereduan ikasi du; \% 49,6k goi-mailako ikasketak ditu eta Batxilergoko ikasketak ditu \% 27,4k; etxetik kanpo lan egiten dute; bizimodu urbanoagoa dute eta erosoago bizi dira (Lasarte et al., 2016). Euren hitzetan estatus ekonomiko bat dute. Beraz, Kabeerren (1999) hitzetan, agentzia lortzeko premisa inportantea dute: jakintza eta estatus ekonomikoa.

Agentziarekin batera, azken hamarkadetan belaunaldi berri bat baino gehiago belaunaldi ezberdinen topaketa gertatu da. Showalterrek aipatzen zuen emakumeen diskurtso propioa (Showalter, 1983) edota kasu honetan bertsokera azaldu da. Estetika diferenteak, begirada propio bat, ertzari begiratzea, enpatia eta xehetasunak, bertsokeraren ezaugarriak ez ezik estilo berri bat ere egungo bertsolaritzan. Esan nahi da, Showalterrek (1983) aipatutako hiru aldiak batera suertatu direla emakumeak bisibilizatzen hasten diren unetik. Horrela, oraindik orain baditugu emakume bertsolariak gizonezkoak paradigmatzat dituztenak, emakume bertsolari feministak euren espazioaren alde borrokan ari direnak, eta emakume bertsolariak ahots propioa ez ezik bertsokera berri bat, estilo berri bat ere sortzen ari direnak (Lasarte et al., 2016).

Ondorio orokor gisa eta bukatzeko, ondoriozta genezake antzinako emakume bertsolariek kantatu zutelako existitzen direla gaur egungo emakume bertsolariak. Eta ordutik honantz nahiz eta bertso-eskolen sorrerak emakume bertsolarien izaera ikusgarri bihurtu, emakume bertsolariek botere-gatazkan erresistitzen eta negoziatzen jardun dutela gaur arte. Horren ondorioz, barne- eta talde-boterea 
landu dute, barne-kontzientzia urteen joanean garatuz eta azken hamarkadetan kontzientzia kolektiboa sortuz (Mosedale, 2005). Egun boterea negoziatzen ari dira bertsogintzaren botereguneetan, agentzia berreskuratzeko bidean (Kabeer, 1999); baina ber denboran, kantuan darraite bertsoaren poetika eta estetika propioa jorratuz, iraganeko aldi androzentrikotik generorik gabeko etorkizunari bertsokera eta pentsaera berri bat luzatuz.

\section{Bibliografia}

Aretxaga, Begoña (1988): Los funerales en el nacionalismo radical, La Primitiva Casa Baroja. Aubert, Adriane; García, Carma eta Racionero, Sandra (2009): «El aprendizaje dialógico», Cultura y Educación, 21(2), 129-13.

Barandiaran, Alberto (2011): Beste larogei urtian, Euskal Herriko Bertsozale Elkartea, Donostia.

Blandón, Maria Teresa; Clara Murguialday eta Norma Vazquez (2011): Los cuerpos del feminismo nicaragüense, Programa Feminista La Corriente, Managua.

Bisquerra, Rafael (2004): Metodología de la investigación educativa, La Muralla, Madril.

De Garibay, Esteban (1854): Memorial histórico español, VII, Imprenta y Editorial Maestre, Madril.

Bolivar, Antonio eta Domingo, Jesus (2006): «La investigación biográfica y narrativa en Iberoamérica: Campos de desarrollo y estado actual», Forum Qualitative Social Research, 7(4), 12 art.

Bourdieu, Pierre (2000): La dominación masculina, Anagrama, Bartzelona.

Caro Baroja, Julio (1972): Los Vascos y la Historia a través de Garibay, Txertoa, Donostia. , (1977, 2000): Los Vascos, Istmo, Madril.

Coffey, Amanda eta Atkinson, Paul (2003): Encontrar el sentido a los datos cualitativos, Contus, Medellin.

Del Valle, Teresa (1985): Mujer vasca imagen y realidad, Anthropos, Bartzelona.

Elliot, John et al. (1986): Investigación-acción en el aula, Conselleria de Cultura, Valentzia.

Epelde, Edurne, Aranguren, Miren \& Retolaza, Iratxe (2015): Gure genealogia feministak. Euskal Herriko mugimendu feministaren kronika bat.

Erkiaga, Nerea (2008): Genero ikuspegia Bertsolaritzaren mugimendu barruan, EHU, Bilbo, Partaidetza eta Komunitate Garapen Masterra, 2015eko martxoan, <http://www.bertsozale.eus/eu/generoa/dokumentazioa/artikuluak/2008\%20 Nere\%20Erkiaga Generoaren\%20ikuspegia\%20Bertsolaritzaren\%20kultur\%20 mugimenduaren\%20barruan.pdf $>$.

Esteban, María Luz (2011): «Cuerpos y políticas feministas: el feminismo como cuerpo», in Cristina Villalba Augusto eta Nacho Álvarez Lucena, Cuerpos Políticos y Agencia, Universidad de Granada, Granada, 9-21.

Fernández, Mercedes (2012): Escuela de Empoderamiento para las Mujeres. Nuevas experiencias de formación y transformación feminista en la sociedad vasca, trabajo fin de máster sin publicar, Universidad del País Vasco (EHU/UPV).

Foucault, Michel (1972): The archaeology of knowledge, translated from the French by A. M. Sheridan Smith, Pantheon, New York, bol. 24.

Freire, Pablo. (1986): La pedagogía de los oprimidos, Siglo XXI, Mexiko.

Freire, Paulo (1999): A la sombra de este árbol, El Roure, Bartzelona.

Garzia, Joxerra (2012): Bertsolaritza, Basque Institute, Etxepare, Donostia.

Goetz, Judith eta Lacompte, Margaret (1988): Etnografía y diseño cualitativo en investigación educativa, Morata, Madril. 
Gramsci, Antonio (1971): Selections from the Prison Note Book, Lawrence and Wishat, Londres.

Habermas, Jürgen (1994): Teoría de la acción comunicativa, Cátedra, Madril.

Hernandez, Jone Miren (2007): Euskara, comunidad e identidad. Elementos de transmisión, elementos de transgresión, Ministerio de Educación, Cultura y Deporte, Área de Cultura, Madril.

(2006/2007): «Emakume bertsolariak: ahozkatu gabeko identitatea», Kobie: antropologia cultural, 12, 61-70.

, (2014): «Emakume bertsolariak: bertsotik bertsora, hanka puntetan», in autoreak (ed.), Gorputza eta generoa: Teoria didaktika eta esperientziak, 37-48.

Ibarzabal Salegui, Nerea (2016): Bertso eguna 2016: bertso-ikuskizuna eta genero-ikuspegia, Gradu Amaierako Lana, <https://addi.ehu.es/handle/10810/18970>.

Izagirre, Estitxu (2014): Bidea urratu duten bertsolariak, Argia, Lasarte.

Juliano, Dolores. (1992): El juego de las astucias: mujer y construcción de modelos sociales alternativos, Horas y Horas, Madril.

Juliano, Dolores (1998): Las que saben. Subculturas femeninas, Horas y Horas, Madril.

Kabeer, Naila (1999): «Resources, agency, achievementes:reflections and measurements of women enpowerment», Development and Change, 30(3), 435-464. doi: 10.1111/1467-7660.00125

Larrañaga, Carmen (1995): «El Bertsolarismo: una tradición oral transitada por el génerosexo», Cuadernos de Sección. Historia y Geografía, 23, 405-425.

Larrañaga, Jexux (2013): Jolas sakona: Txapelketaren prozesu errituala eta bertsolariaren arrazoi sortzailea XXI mendeko agoran, Euskal Herriko Unibertsitatea, Bilbo.

Lasarte, Gema et al. (2015): Generoa eta bertsolaritza [ikerketa argitaragabea].

et al. (2016): Emakume bertsolariak: ahanzturatik diskurtso propiora, Emakunde, Instituto Vasco de la Mujer del Gobierno Vasco, Gasteiz-Vitoria.

León, Magdalena (1999): «Poder y empoderamiento de las mujeres», Región y sociedad, 11(18).

Limon, Ma Rosario \& Crespo, Juan Antonio (2002): Grupos de debate para mayores. Guía práctica para animadores, Narcea, Madril.

Lukes, Steven. (1974): Power. A radikal Wiew, Macmillan, Londres.

Malhotra, Anju; Schuler, Sidney Ruth eta Boender, Carol (2002): «Measuring women's empowerment as a variable in international development», Background paper prepared for the World Bank Workshop on Poverty and Gender: New Perspectives, 1-59.

Mosedale, Sarah (2005): «Assessing women's empowerment: towards a conceptual framework», Journal of international development, 17(2), 243-257.

Murguialday, Clara (2006): Empoderamiento de las mujeres: conceptualización y Estrategias. Berreskuratua 2018ko abenduan: <http://www.vitoria-gasteiz.org/wb021/http/ contenidosEstaticos/adjuntos/es/16/23/51623.pdf>.

, (2013): Reflexiones feministas sobre el empoderamiento de las mujeres, Colección Cooperació, Agencia Catalana de Cooperació al Desenvolupament.

Oakley, Peter (ed). (2001): Evaluating Empowerment: Reviewing the Concept and Practice, INTRAC, Oxford.

Ortner, Sherry (2006): Anthropology and Social Theory: Culture, Power, and the Acting Subject, Duke University Press, Durham, NC.

Rapley, Tim (2014): Los análisis de la conversación, del discurso y de documentos en Investigación Cualitativa, Morata, Madril.

Rodríguez, Gregorio; Gil, Javier eta García, Eduardo (1996): Análisis de los datos cualitativos asistidos por ordenador: aguad y Nudist, PPU, Bartzelona. 
Rowlands, Jo (1997): Questioning Empowerment, Oxfman Publications, Oxford.

Showalter, Elaine (1983): A Literature of Their Own, British Women Novelists from Brontë to Lessing, Princeton, Virago, Londres.

Spivak, Gayatri Chakravorty (1993): "Can the subaltern speak?», in P. Williams eta L. Chrisman. (ed), Colonial Discourse and Post-colonial Theory: A Reader, Harvester Wheatsheaf, Londres (or. 90105).

Tolbert, Eizabeth (1990): «Women cry with words: Symbolization of affect in the Karelian lament», Yearbook for Traditional Music, 22, 80-105.

, (2016): Female vocality and performative efficacy in the Finnish-Karelian itkuvirsi, EHU/UPV, Udako Ikastaroak.

Ugalde et al. (2018): «Mujeres vascas improvisadoras: las bertsolaris del mundo tradicional (siglos XV-XIX)», Arenal aldizkariko hurrengo alean publikatzeko.

Vizcarra, Maria Teresa; Macazaga, Ana Maria eta Rekalde, Itziar (2009): Eskolako kirol lehiaketan neskek dituzten baloreak eta beharrak, Emakunde eta UPV/EHU, Bilbo. 

